\title{
SOLID LIPID NANOPARTICLES: A PROMISING APPROACH FOR COMBINATIONAL DRUG THERAPY IN CANCER
}

\author{
RITA R. LALA*, AMOL S. SHINDE, NIKITA Y. NANDVIKAR
}

Department of Pharmaceutics, Prin. K. M. Kundnani College of Pharmacy Mumbai 400005, Maharashtra, India
Email: r_r_lala@yahoo.co.in

Received: 11 Jun 2018, Revised and Accepted: 21 Jul 2018

\begin{abstract}
Combination therapy for cancer treatment is accepted worldwide due to the generation of synergistic anticancer effects; restrain in multidrug resistance (MDR) or tumor resistance by different mechanisms of action and minimization of dose-dependent toxicity. Recently developed Solid lipid nanoparticles (SLNs) are matrix composed of lipid which is solid at both room and body temperature and hence it is as an alternative to other nanocarrier systems. SLNs after oral administration get absorbed by lymphatic pathway due to stimulation of chylomicron formation. Thus, it avoids all consequences related to an oral drug delivery system and improves oral bioavailability. SLNs based combination drug delivery to tumor tissues reduces the problems associated with chemotherapy. The targeted and sustained delivery of chemotherapeutic agents reduces the dose by achieving high concentrations at the target site, without altering the normal tissues. In this article, we have reviewed and focused on SLNs as a drug delivery system; ingredients used in formulating SLNs and developed two or more drugs in a single formulation of SLNs as drug delivery. This article also focuses on the fact that SLNs as a combination drug delivery provides an attractive approach in future prevention and beneficial for the treatment of cancer by increasing its therapeutic efficacy.
\end{abstract}

Keywords: Nanodrug delivery, Solid Lipid Nanoparticles, Tumor, Combinational Chemotherapy, Multidrug Resistance

(C) 2018 The Authors. Published by Innovare Academic Sciences Pvt Ltd. This is an open access article under the CC BY license (http://creativecommons.org/licenses/by/4.0/) DOI: http://dx.doi.org/10.22159/ijap.2018v10i5.27894

\section{INTRODUCTION}

Cancer has been listed as one of the most challenging to treat diseases. Genetic alterations and cellular abnormalities are noticed in cancer. The aggressive growth of cancer cells promoted by the intricacy and heterogeneity of abnormal and altered cells leads to significant morbidity and mortality in patients $[1,2]$. Cancer studies show that the survival rates improved but mortality rates still remained high for some specific tumors. To enhance the effectiveness of cancer treatment, effective therapeutic methods with the least side effects along with and precise diagnostics are essential [3]. In anticancer therapy, various chemotherapeutic agents are used which are targeted on specific multiple pathways. Nevertheless, a single agent prescribed repetitively in the treatment consequences in resistance to chemotherapy (specific drug) or development of MDR [4].

Problems associated with conventional single-drug chemotherapy include limited accessibility of the drug to tumor tissues requiring an additional dose and leading to intolerable cytotoxicity with specific targeting not being achieved. To avoid these hindrances in cancer therapy, combinatorial chemotherapy is preferred clinically. Combinatorial therapy consists of two or more therapeutic agents administered concurrently or use of different therapies in combined form. Currently, four therapies are preferred in cancerchemotherapy, hormone therapy, immunotherapy, radiotherapy. Simultaneously chemotherapy or hormones or immunosuppressants are given together in combinatorial therapy [5]. Combinatorial therapy decreases the side effects of individual drug therapy by taking into consideration synergistic effect of two drugs administered in a single dosage form, countering different biological signaling pathways in a synergistic manner, possibly minimizing dosage of each drug or accessing specific multi-target mechanisms, insufficient transportation through membrane, inadequate bioavailability and least biodistribution can thus be overcome [5]. This approach may be helpful in enhancing the therapeutic efficacy of drugs since it attacks different stages of cancer cell growth cycles [6].

Currently, nanotechnology is developing into a rapidly growing field with applications in health and drug therapy. Nanoparticles have a small size and high surface area. The nano-size distribution effect is due to some physical and chemical properties [7]. Various types of nano drug delivery systems are nanoparticles, dendrimers, nanotubes, micelles and liposomes. Nanotechnology-based combinational drug delivery systems increase the bioavailability by enhancing permeability, retention and reaching the cancers tissues target site [8]. It helps to conquer the systemic toxicity towards normal tissue and adverse effects which result from conventional cancer therapeutic agents [5]. SLNs are a drug delivery system consisting of a drug carrier which helps in increasing bioavailability and reducing erratic absorption [7, 9]. In this review, we discuss nanotechnology based SLNs for combinational drug delivery in cancer therapy as a novel promising drug delivery system. This article is an updated and comprehensive review discussing the progress and applications of SLNs from various published reviews and research (national and international) in the field in the last two decades.

Advantages of combinational drug delivery in cancer therapy mentioned in (fig. 1)

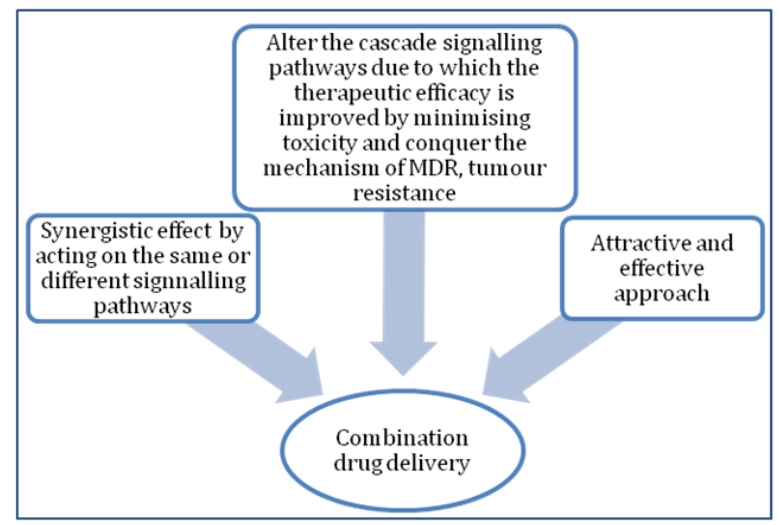

Fig. 1: Advantages of combinational drug delivery [5]

\section{SLNs}

SLNs are colloidal nanoparticlate delivery systems with a nano-size distribution ( 50 to $1000 \mathrm{~nm}$ ) made from lipids which remain in solid state at room temperature and body temperature, stabilized by surfactants. SLNs can be easily prepared by using several types of lipids including lipid acids which are mono, di or triglycerides, 
glycerides mixtures or waxes, and stabilized by using compatible surfactants i.e. Non-ionic or ionic [10]. SLNs can be used for several purposes and overcome the problems associated with other colloidal carriers. They lead to enhancement of drug solubility, controlled drug release, reaching the target site enabling site targeting, reduction in the therapeutic dose regimen, prevention of degradation of incorporated labile drugs, tremendous permissibility, increase the bioavailability of drug [7, 11-13]. SLNs have been developed and recommended for administering to several different routes of administration like oral, topical, parenteral; and pulmonary [7]. Absorption of nanoparticles takes place through mucosa of the intestine by several mechanisms namely through the Payer's patches, by intracellular uptake or by the paracellular pathway [14].

Rationale of SLNs for Cancer: Tumor cells are having defective, leaky vascular structure due to poorly regulated nature of tumor angiogenesis. Due to lymphatic system drained interstitial fluid within a tumor, the submicron-sized particulate matter may preferentially extra vasate into the tumor and be retained there. This is called as "enhanced permeability and retention" (EPR) effect.
EPR effect can be considered while designing Nano particulate drug delivery. Thus, SLN system is designed in such a way to achieve passive tumor targeting by taking advantage of EPR effect [10].

\section{Lipids and emulsifiers used in SLN formulations}

General ingredients for SLN include solid lipids, emulsifiers and solvent/water. The two phases i.e. lipid and aqueous should be mixed thoroughly to form one homogenous phase with droplet size in the nanometer $(\mathrm{nm})$ range. Subsequently, these particles are allowed to solidify by cooling or solvent evaporation depending on the employed method of preparation. The emulsifiers are preferred on the basis of drug solubility, HLB values as per Griffith scale and type of emulsion being formulated for particular drug or drugs used in combination. Several types of lipids used presently include triglycerides, partial glycerides, fatty acids, steroids and waxes. Emulsifiers and their combinations have been used to stabilize the lipid dispersion. It has been found that a combination of emulsifiers efficiently prevents the agglomeration of particles $[15,16]$. Ingredients used in SLNs are given in (table 1).

Table 1: Lipids and emulsifiers used in SLN formulations

\begin{tabular}{|c|c|c|}
\hline \multirow{2}{*}{\multicolumn{3}{|c|}{\begin{tabular}{|l|} 
Lipids \\
Triglycerides
\end{tabular}}} \\
\hline & & \\
\hline \multicolumn{2}{|c|}{ (Glycerol Tricaprate) } & (Glycerol Tricaprate) \\
\hline Tristearin & (Glycerol Tristearate) & [17] \\
\hline Trilaurin & (Glycerol Trilaurate) & [18] \\
\hline Tri-myristin & (Glycerol Trimyristate) & [19] \\
\hline Tri-palmitin & (Glycerol Tripalmitate) & [20] \\
\hline \multicolumn{2}{|l|}{ Hydrogenated coco-glycerides (Softisan 142) } & [21] \\
\hline \multicolumn{2}{|l|}{ Hard fat types } & [22] \\
\hline \multicolumn{2}{|l|}{ Witepsol W 35} & [23] \\
\hline \multicolumn{2}{|l|}{ Witepsol H 35} & [24] \\
\hline \multicolumn{2}{|l|}{ Witepsol H 42} & [25] \\
\hline \multicolumn{2}{|l|}{ Witepsol 085} & [24] \\
\hline \multicolumn{2}{|l|}{ Glyceryl monostearate (Capmul GMS-40) } & [26] \\
\hline \multicolumn{2}{|l|}{ Glycerylbehenate (Compritol 888 ATO) } & {$[27,28]$} \\
\hline \multicolumn{2}{|l|}{ Glycerylpalmitostearate (Precirol ATO 5) } & [22] \\
\hline \multicolumn{2}{|l|}{ Cetylpalmitate } & [29] \\
\hline \multicolumn{2}{|l|}{ Stearic acid } & [30] \\
\hline \multicolumn{2}{|l|}{ Palmitic acid } & [27] \\
\hline \multicolumn{2}{|l|}{ Decanoic acid } & [31] \\
\hline \multicolumn{2}{|l|}{ Behenic acid } & [32] \\
\hline \multicolumn{3}{|l|}{ Emulsifiers/Coemulsifiers } \\
\hline \multirow{2}{*}{\multicolumn{2}{|c|}{$\begin{array}{l}\text { Soybean lecithin } \\
\text { (Lipoid S 75, Lipoid S 100) }\end{array}$}} & {$[32,33]$} \\
\hline & & \\
\hline \multicolumn{2}{|l|}{ Egg lecithin (Lipoid E 80) } & [20] \\
\hline \multicolumn{3}{|l|}{ Phosphatidylcholine } \\
\hline \multicolumn{2}{|l|}{ (Epikuron 170, Epikuron 200) } & {$[15,34]$} \\
\hline \multicolumn{2}{|l|}{ Poloxamer 188} & [35] \\
\hline \multicolumn{2}{|l|}{ Poloxamer 182} & [36] \\
\hline \multicolumn{2}{|l|}{ Poloxamer 407} & [37] \\
\hline \multicolumn{2}{|l|}{ Poloxamine 908} & [37] \\
\hline \multicolumn{3}{|l|}{ Tween 20} \\
\hline \multicolumn{2}{|l|}{ Tween 80} & [38] \\
\hline Span 80 & & [39] \\
\hline Sodium cholate & & [36] [39] \\
\hline Sodium glycocholate & & {$[40,41]$} \\
\hline Taurocholic acid sodium salt & & [42] \\
\hline Taurodeoxycholic acid sodium salt & & [43] \\
\hline Butanol & & [44] \\
\hline Butyric acid & & [45] \\
\hline Dioctyl sodium sulfosuccinate & & [46] \\
\hline Monooctylphosphoric acid sodium & & [47] \\
\hline
\end{tabular}

\section{Techniques of SLNs preparation}

The different techniques used to formulate the SLNs, their merits and demerits are mentioned in table 2 .

\section{Influence of ingredient composition on product quality}

\section{Influence of the lipid}

The composition and quality of lipids may be varied from different suppliers and different batches from the same suppliers. Thus, these slight changes in composition might extensively influence the quality of SLN dispersion [15]. The increments in lipid concentration also reduce the leaking of the drug into the external phase, which positively influences entrapment efficiency [48] and however the subsequent increase in particle size with increase in lipid amount significantly causing an increase in viscosity of the dispersion thus resulting in particle agglomeration [43]. Several research studies have reported that increasing lipid concentration results in larger particles, high entrapment efficiency and broader particle size distribution and a higher poly-dispersity index as well [50] 
Table 2: Merits and demerits of SLNs preparation methods

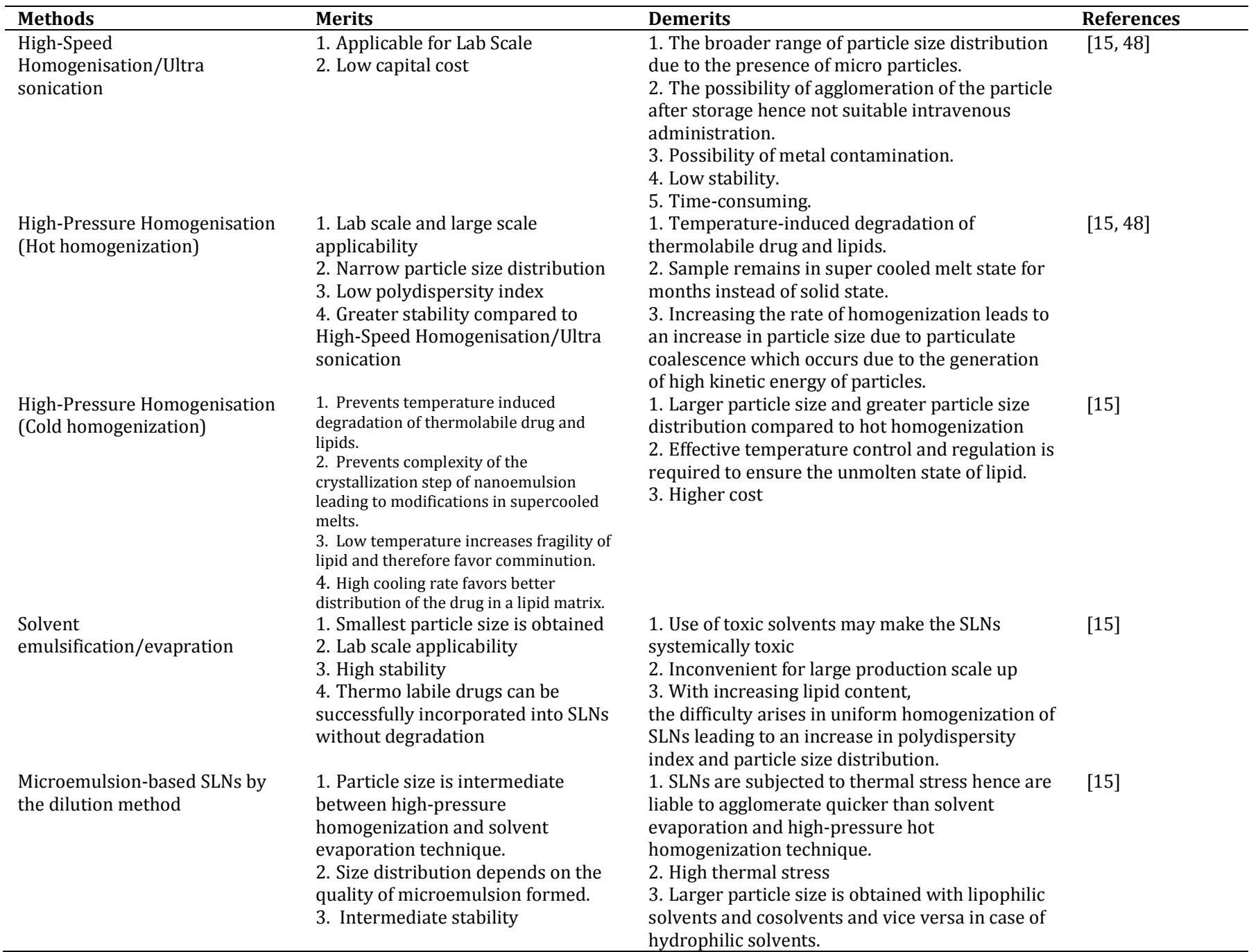

Table 3: Developed and formulated combinatorial nanoparticles for cancer therapy

\begin{tabular}{|c|c|c|c|c|}
\hline $\begin{array}{l}\text { Author } \\
\text { name }\end{array}$ & Drugs & $\begin{array}{l}\text { Cell line/type of cancer } \\
\text { cells }\end{array}$ & Results & References \\
\hline $\begin{array}{l}\text { Nazzal } \\
\text { Sami et al. }\end{array}$ & $\begin{array}{l}\text { Simvastatin, } \\
\text { Tocotrienol }\end{array}$ & $\begin{array}{l}\text { Malignant+SA mammary } \\
\text { epithelial cells }\end{array}$ & $\begin{array}{l}\text {-In vitro studies showed their antiproliferative effects on } \\
\text { malignant+SA mammary epithelial cells } \\
\text {-The potency of combination therapy was confirmed }\end{array}$ & {$[54]$} \\
\hline $\begin{array}{l}\text { Jayakumar } \\
\text { R et al. }\end{array}$ & $\begin{array}{l}\text { Curcumin (CUR), } 5 \\
\text { Fluorouracil ( } 5 \text { FU) }\end{array}$ & Colon cancer cells (HT29) & $\begin{array}{l}\text { - The collective exposure of the nanoformulations in colon } \\
\text { cancer cells (HT 29) proved beneficial. } \\
\text {-Enhanced anticancer effects in vitro and in vivo } \\
\text { synergistically. }\end{array}$ & {$[55]$} \\
\hline Han J et al. & $\begin{array}{l}\text { All-trans-retinoic acid } \\
\text { (ATRA), Paclitaxel } \\
\text { (PTX) }\end{array}$ & HepG2 cells & $\begin{array}{l}\text {-ATRA chitooligosaccharide (RCOS) nanoparticles could be } \\
\text { rapidly and continuously taken up by HepG2 cells via } \\
\text { endocytosis and transported into the nucleus, and the } \\
\text { uptake rates increased with particle concentration. } \\
\text {-The RCOS nanoparticles have promising potential as drug } \\
\text { carriers for co-delivery of both drugs together }\end{array}$ & {$[56]$} \\
\hline $\begin{array}{l}\text { Sahoo SK et } \\
\text { al. }\end{array}$ & CUR, Temozolomide & T-98G cells & $\begin{array}{l}\text {-The dual drug loaded MNPs formulations showed the } \\
\text { higher cytotoxic effect and higher therapeutic efficacy. } \\
\text {-The formulation showed a synergistic effect against HepG2 } \\
\text { cells. }\end{array}$ & {$[57]$} \\
\hline $\begin{array}{l}\text { Cho CW et } \\
\text { al. }\end{array}$ & PTX, Verapamil (VP) & MCF7 cells & $\begin{array}{l}\text {-PVSV (PTX and VP co-loaded SLN, later added VP) were } \\
\text { prepared to overcome MDR by a combination of PTX and } \\
\text { VP. } \\
\text {-PVSV showed significantly higher cytotoxicity and cellular } \\
\text { uptake, down-regulated the expression of p-gp than PTX } \\
\text { solution in MCF-7/ADR resistant cells. } \\
\text {-PVSV exhibited great potential for breast cancer therapy }\end{array}$ & [58] \\
\hline
\end{tabular}




\begin{tabular}{|c|c|c|c|c|}
\hline $\begin{array}{l}\text { Wang S et } \\
\text { al. }\end{array}$ & CUR, 5 FU & SMMC-7721 cells & $\begin{array}{l}\text {-SLN-CUR and LDH (Layered double hydroxides) 5-FU } \\
\text { showed a significant synergetic effect on SMMC-7721 cells } \\
\text { which was stronger than plain drugs together. } \\
\text {-FACS analysis proved that the combination of SLN- } \\
\text { curcumin and LDH-5-FU induced } 80.1 \% \text { apoptosis in } \\
\text { SMMC-7721 cells, which were } 1.7 \text {-folds of the sum of the } \\
\text { two plain drugs loaded. }\end{array}$ & [59] \\
\hline $\begin{array}{l}\text { Dianzani C } \\
\text { et al. }\end{array}$ & $\begin{array}{l}\text { Doxorubicin (DOX), } \\
\text { PTX }\end{array}$ & $\begin{array}{l}\text { Colorectal cancer cell line } \\
\text { HT-28 }\end{array}$ & $\begin{array}{l}\text {-SLNs of cholesteryl-butyrate (aprodrug of butyrate), DOX } \\
\text { or PTX and evaluated the antiproliferative effect on human } \\
\text { colorectal cancer cell line HT-28. } \\
\text {-The combination formulations have higher cytotoxicity } \\
\text { than the individual drug treatment. }\end{array}$ & [45] \\
\hline $\begin{array}{l}\text { Wu Yu Xiao } \\
\text { et al. }\end{array}$ & $\begin{array}{l}\text { DOX, } \\
\text { chemosensitizer, } \\
\text { GG918, }\end{array}$ & $\begin{array}{l}\text { MDR breast cancer cell line } \\
\text { (MDA435/lCC6/MDR1) }\end{array}$ & $\begin{array}{l}\text {-Polymer-lipid hybrid NPS (PLN) was formulated. } \\
\text {-The results confirmed that DOX and GG918 co- } \\
\text { encapsulated PLN formulation showed a greater efficiency } \\
\text { when compared with the single drug formulation on a MDR } \\
\text { breast cancer cell line. }\end{array}$ & {$[60]$} \\
\hline $\begin{array}{l}\text { Thakkar A } \\
\text { et al. }\end{array}$ & $\begin{array}{l}\text { Ferulic acid (FA) and } \\
\text { Aspirin (ASP) }\end{array}$ & $\begin{array}{l}\text { MIA PaCa- } 2 \text { and Panc- } 1 \\
\text { human pancreatic cancer } \\
\text { cells }\end{array}$ & $\begin{array}{l}\text {-The FA and ASPc-SLN (chitosan coated) combination } \\
\text { showed a synergistic inhibition of cell viability and induced } \\
\text { apoptosis in MIA PaCa-2 and Panc-1 human pancreatic } \\
\text { cancer cells. }\end{array}$ & [61] \\
\hline $\begin{array}{l}\text { Prabhu S et } \\
\text { al. }\end{array}$ & $\begin{array}{l}\text { ASP, CUR, } \\
\text { Sulforaphane (SFN) }\end{array}$ & $\begin{array}{l}\text { MIA Paca- } 2 \text { and Panc- } 1 \text { cell } \\
\text { lines }\end{array}$ & $\begin{array}{l}\text {-Cell viability studies and aptosis assay revealed that the } \\
\text { formulation showed synergistic effect. } \\
\text {-It also proved that a nanoparticulate drug delivery } \\
\text { regimen is beneficial for the chemoprevention of pancreatic } \\
\text { cancer }\end{array}$ & [62] \\
\hline $\begin{array}{l}\text { Gulay B et } \\
\text { al. }\end{array}$ & PTX, siRNA & HeLa cell line & $\begin{array}{l}\text {-Vaginal suppository was prepared by using PTX and } \\
\text { genetic material which can be applied locally for cervical } \\
\text { cancer. } \\
\text {-SiRNA was selected as genetic material which inhibits } \\
\text { BCL2 oncogene. This combination were incorporated into } \\
\text { SLNs and dispersed separately in vaginal suppositories. } \\
\text {-This formulation indicated that vaginal suppository } \\
\text { containing SLNs can brought the advantages of the } \\
\text { simultaneous delivery of PTX and siRNA via vaginal route. }\end{array}$ & [63] \\
\hline Li S et al. & $\begin{array}{l}\text { Docetaxel (DTX), } \\
\text { Baicalein (BA) }\end{array}$ & Lung cancer cells & $\begin{array}{l}\text {-Transferrin tinted DTX and BA loaded SLNS (Tf-D/B-SLNs) } \\
\text { were prepared. } \\
\text {-(Tf-D/B-SLNs) is having ability to suppress lung cancer } \\
\text { cells in vitro and in vivo was investigated. The best tumor } \\
\text { inhibition ability and the lowest systemic toxicity were } \\
\text { observed. }\end{array}$ & [64] \\
\hline $\begin{array}{l}\text { Torchilin } \\
\text { VP et al. }\end{array}$ & $\begin{array}{l}\text { DOX, } \alpha \text {-tocopherol } \\
\text { succinate (TOS) }\end{array}$ & $\begin{array}{l}\text { MCF-7/Adr and NCI/Adr } \\
\text { cancer cell lines }\end{array}$ & $\begin{array}{l}\text {-Drug-resistant cancer cells in monolayer and spheroid } \\
\text { model were selected for study. } \\
\text {-The SLN co-loaded with Dox and TS showed a stronger } \\
\text { cytotoxicity against MCF-7/Adr and NCI/Adr cells as } \\
\text { compared to Single drug. } \\
\text {-The co-delivery of both drugs in SLN showed a promising } \\
\text { approach for combination cancer therapy. }\end{array}$ & [65] \\
\hline $\begin{array}{l}\text { Gulay B et } \\
\text { al. }\end{array}$ & PTX, Herceptin & MDA-MB-453 cell line & $\begin{array}{l}\text {-PTX-loaded cationic SLN/Herceptin complexes were more } \\
\text { toxic to MDA-MB- } 453 \text { cell line. } \\
\text {-In vitro results proved this combinational therapy is } \\
\text { beneficial for the treatment of cervical cancer therapy. }\end{array}$ & [66] \\
\hline Bo Liu et al. & $\begin{array}{l}\text { PTX, } \alpha \text {-tocopherol } \\
\text { succinate } \\
\text { cisplatinprodrug } \\
\text { (TOS-CDDP) }\end{array}$ & HeLa Cells & $\begin{array}{l}\text {-Trans-activating transcriptional activator (TAT)-modified } \\
\text { SLNs for co-delivery of PTX and TOS-CDDP were } \\
\text { formulated. TAT PTX/TOS-CDDP SLNs showed a synergistic } \\
\text { effect in the suppression of cervical tumor cell growth. } \\
\text {-They showed high tumor tissue accumulation, superior } \\
\text { antitumor efficiency, and much lower toxicity in vivo. }\end{array}$ & [67] \\
\hline $\begin{array}{l}\text { Prabhu S et } \\
\text { al. }\end{array}$ & $\begin{array}{l}\text { Ibuprofen (IBU), } \\
\text { sulforaphane (SFN) }\end{array}$ & Panc- 1 and MIA PaCa- 2 cells & $\begin{array}{l}\text {-IBU-SLN combination with SFN showed a synergistic } \\
\text { inhibition of cell viability in human pancreatic cancer cells. } \\
\text {-Cell-based assay and formulation studies revealed that low } \\
\text { dose of IBU which was encapsulated in SLN formulation to } \\
\text { prevent pancreatic cancer. }\end{array}$ & [68] \\
\hline $\begin{array}{l}\text { Wang X et } \\
\text { al. }\end{array}$ & PTX, DOX & NCL-H460 cells & $\begin{array}{l}\text {-PTX-DOX NLC achieved the highest cytotoxic effect. } \\
\text {-In vivo investigation on NSCLC animal models showed that } \\
\text { co-delivery of PTX and DOX possessed high tumor-targeting } \\
\text { capacity and strong antitumor activity. }\end{array}$ & [69] \\
\hline
\end{tabular}

\section{Influence of the emulsifier}

The selection of the emulsifiers and their concentration has great importance on the dispersion quality of SLNs [51]. The surface tension reduces and supports the particle partitioning during homogenization when the concentration of the emulsifier is higher. During high pressure homogenization, the surface area increases very rapidly due to high pressure being applied on the dispersion leading to particle size reduction. Hence, the kinetic aspects have to be considered [15]. To some extent, the concentration of surfactant does affect, but once 
the optimal concentration is reached, it may not significantly influence the particle size [52]. The primary process covers the new surfaces which compete with the agglomeration of uncovered lipid surfaces. The primary dispersion should contain an excessive quantity of emulsifier, which should cover the new surfaces rapidly. It has been reported that SLNs stabilized using combination of surfactants having lower particle size range and higher stability as compared to formulations having only one surfactant [15]. As per the reported studies, Tween 80 and Poloxamer 188 in combination showed lowest particle size and polydispersity index when it compared with Tween 80 alone. The presence of two surfactants i.e. Tween 80 and Pol-188 rapidly covered the new lipid surfaces generated during the shearing process thereby, avoiding aggregation and increasing surface area. Also the combination of emulsifiers and their HLB values could lead to different surface absorption [53].

\section{Developed and formulated combinatorial nanoparticles for cancer therapy}

Some research has been carried out on the combinatorial SLNs these literatures mentioned in table 3 .

\section{CONCLUSION}

The goal of cancer treatment in the modern era is to target the cancerous cell without affecting normal cells selectively. Cancer therapy is extremely complicated, thus to overcome the problems with conventional therapy. Nano drug delivery is focused on SLNs combinatorial formulations having an optimal effect on tumor cells and can be delivered in a more effective way. SLNs have the potential to reduce the dose by reaching the target site, emphasizing on the synergistic effect of drugs used together thus the normal cells are not affected or only to a lesser extent resulting in a reduction of the dose associated toxicity of both drugs. The combinatorial approach in oncology with chemotherapeutic drugs using SLNs as a suitable Nano carrier could improve therapeutic efficacy, increase bioavailability and prevent tumor resistance. This approach could be considered as an innovative, promising, beneficiary approach for cancer therapy and supportive of achieving the desired therapeutic effect in a minimal dose of chemotherapeutic agents.

\section{AUTHORS CONTRIBUTIONS}

All the author have contributed equally

\section{CONFLICT OF INTERESTS}

The authors have declared no conflict of interest

\section{REFERENCES}

1. Das M, Mohanty C, Sahoo SK. Ligand-based targeted therapy for cancer tissue. Expert Opin Drug Delivery 2009;6:285-304.

2. Mohanty C, Das M, Kanwar MR, Sahoo SK. Receptor-mediated tumor targeting: an emerging approach for cancer therapy. Curr Drug Delivery 2011;8:45-58.

3. Abbasi AZ, Prasad P, Cai P, He C, Foltz WD, Amini MA, et al. Manganese oxide and docetaxel co-loaded fluorescent polymer nanoparticles for dual modal imaging and chemotherapy of breast cancer. J Controlled Release 2015;209:186-96.

4. Persidis A. Cancer multi drug resistance. Nat Biotechnol 1999;17:94-5.

5. Parhi P, Mohanty C, Sahoo SK. Nanotechnology-based combinational drug delivery: an emerging approach for cancer therapy. Drug Discovery Today 2012;17:1044-52.

6. Dilnawaz F, SK Sahoo. Research paper Enhanced accumulation of curcumin and temozolomide loaded magnetic nanoparticles executes profound cytotoxic effect in glioblastoma spheroid model. Eur J Pharm Biopharm 2013;85:452-62.

7. Yassin AE, Albekairy A, Alkatheri A, Sharma RK. Anticancerloaded solid lipid nanoparticles: high potential advancement in chemotherapy. Dig J Nanomater Biostruct 2013;8:905-16.

8. Kadian R. Nanoparticles: a promising drug delivery approach. Asian J Pharm Clin Res 2018;11:30-5.

9. Ponchel G, Montisci MJ, Dembri A, Durrer C, Duchêne D. Mucoadhesion of colloidal particulate systems in the gastrointestinal tract. Eur J Pharm Biopharm 1997;44:25-31.
10. Wong HL, Bendayan R, Rauth AM, Li Y, Wu XY. Chemotherapy with anticancer drugs encapsulated in solid lipid nanoparticles. Adv Drug Delivery Rev 2007;59:491-504.

11. Sarath Chandran IA. Review on nanotechnology in solid lipid nanoparticles. IJPDT 2012;2:45-61.

12. Senthil Kumar P, Arivuchelvan A, Jagadeeswaran A, Subramanian N, Senthil Kumar C, Mekala P. Formulation, optimization and evaluation of enrofloxacin solid lipid nanoparticles for sustained oral delivery. Asian J Pharm Clin Res 2015;8:231-6.

13. Kaliamurthi S, Selvaraj G. Insight on solid lipid nanoparticles: characterization and application in diabetes mellitus. J Crit Rev 2016;3:11-6.

14. Pinto JF, Müller RH. Pellets as carriers of solid lipid nanoparticles (SLN) for oral administration of drugs. Pharmazie 1999;54:506-9.

15. Mehnert W, Mäder K. Solid lipid nanoparticles: production, characterization and applications. Adv Drug Delivery Rev 2001;47:165-96.

16. Cavalli R, Caputo O, Gasco MR. Solid lipospheres of doxorubicin and idarubicin. Int J Pharm 1993;89:R9-R12.

17. Esposito E, Fantin M, Marti M, Drechsler M, Paccamiccio L, Mariani $\mathrm{P}$, et al. Solid lipid nanoparticles as delivery systems for bromocriptine. Pharm Res 2008;25:1521-30.

18. Patravale VB, Ambarkhane AV. Study of solid lipid nanoparticles with respect to particle size distribution and drug loading. Die Pharmazie-An Int J Pharm Sci 2003;58:392-5.

19. Xu W, Lim SJ, Lee MK. Cellular uptake and antitumour activity of paclitaxel incorporated into trilaurin-based solid lipid nanoparticles in ovarian cancer. J Microencapsul 2013;30:755-61.

20. Narala A, Veerabrahma K. Preparation, characterization and evaluation of quetiapine fumarate solid lipid nanoparticles to improve the oral bioavailability. J Pharm 2013:1-8. http://dx.doi.org/10.1155/2013/265741

21. Naguib YW, Rodriguez BL, Li X, Hursting SD, Williams III RO, Cui Z. Solid lipid nanoparticle formulations of docetaxel prepared with high melting point triglycerides: in vitro and in vivo evaluation. Mol Pharm 2014;11:1239-49.

22. Tichota DM, Silva AC, Lobo JM, Amaral MH. Design, characterization, and clinical evaluation of argan oil nanostructured lipid carriers to improve skin hydration. Int J Nanomed 2014;9:3855-64.

23. Ahlin P, Kristl J, Smid-Korbar J. Optimization of procedure parameters and physical stability of solid lipid nanoparticles in dispersions. Acta Pharma 1998;48:259-67.

24. Westesen K, Bunjes H, Koch MH. Physicochemical characterization of lipid nanoparticles and evaluation of their drug loading capacity and sustained release potential. J Controlled Release 1997;48:223-36.

25. Cavalli R, Gasco MR, Morel S. Behaviour of timolol incorporated in lipospheres in the presence of a series of phosphate esters. STP Pharma Sci 1992;2:514-8.

26. Patel MN, Lakkadwala S, Majrad MS, Injeti ER, Gollmer SM, Shah ZA, et al. Characterization and evaluation of 5fluorouracil-loaded solid lipid nanoparticles prepared via a temperature-modulated solidification technique. AAPS PharmSciTech 2014;15:1498-508.

27. Yuan H, Miao J, Du YZ, You J, Hu FQ, Zeng S. Cellular uptake of solid lipid nanoparticles and cytotoxicity of encapsulated paclitaxel in A549 cancer cells. Int J Pharm 2008;348:137-45.

28. Shi F, Zhao JH, Liu Y, Wang Z, Zhang YT, Feng NP. Preparation and characterization of solid lipid nanoparticles loaded with frankincense and myrrh oil. Int J Nanomed 2012;7:2033-43.

29. Carbone C, Campisi A, Musumeci T, Raciti G, Bonfanti R, Puglisi G. FA-loaded lipid drug delivery systems: preparation, characterization and biological studies. Eur J Pharm Sci 2014;52:12-20.

30. Xie S, Zhu L, Dong Z, Wang Y, Wang X, Zhou W. Preparation and evaluation of ofloxacin-loaded palmitic acid solid lipid nanoparticles. Int J Nanomed 2011;6:547-55.

31. Li Y, Taulier N, Rauth AM, Wu XY. Screening of lipid carriers and characterization of drug-polymer-lipid interactions for the rational design of polymer-lipid hybrid nanoparticles (PLN). Pharm Res 2006;23:1877-87. 
32. Tran TH, Choi JY, Ramasamy T, Truong DH, Nguyen CN, Choi HG, et al. Hyaluronic acid-coated solid lipid nanoparticles for targeted delivery of vorinostat to CD44 overexpressing cancer cells. Carbohydr Polym 2014;114:407-15.

33. Zhang Z, Gao F, Bu H, Xiao J, Li Y. Solid lipid nanoparticles loading candesartan cilexetil enhance oral bioavailability: in vitro characteristics and absorption mechanism in rats. Nanomed: Nanotechnol Biol Med 2012;8:740-7.

34. Serpe L, Catalano MG, Cavalli R, Ugazio E, Bosco O, Canaparo R, et al. Cytotoxicity of anticancer drugs incorporated in solid lipid nanoparticles on HT-29 colorectal cancer cell line. Eur J Pharm Biopharm 2004;58:673-80.

35. Chen $\mathrm{H}$, Chang $\mathrm{X}, \mathrm{Du} \mathrm{D}$, Liu $\mathrm{W}$, Liu J, Weng $\mathrm{T}$, et al. Podophyllotoxin-loaded solid lipid nanoparticles for epidermal targeting. J Controlled Release 2006;110:296-306.

36. Almeida AJ, Runge S, Müller RH. Peptide-loaded solid lipid nanoparticles (SLN): influence of production parameters. Int J Pharm 1997;149:255-65.

37. Muller RH, Olbrich C. Solid lipid nanoparticles phagocytic uptake, in vitro cytotoxicity and in vitro biodegradation. $1^{\text {st }}$ communication Pharm Ind 1999;61:462-7.

38. Das $\mathrm{S}, \mathrm{Ng} \mathrm{WK}$, Tan RB. Are nanostructured lipid carriers (NLCs) better than solid lipid nanoparticles (SLNs): development, characterizations and comparative evaluations of clotrimazoleloaded SLNs and NLCs? Eur J Pharm Sci 2012;47:139-51.

39. Ibrahim WM, AlOmrani AH, Yassin AE. Novel sulpiride-loaded solid lipid nanoparticles with enhanced intestinal permeability. Int J Nanomed 2014;9:129-44.

40. Bunjes H, Koch MH, Westesen K. Influence of emulsifiers on the crystallization of solid lipid nanoparticles. J Pharm Sci 2003;92:1509-20.

41. Westesen K, Siekmann B. Investigation of the gel formation of phospholipid-stabilized solid lipid nanoparticles. Int J Pharm 1997;151:35-45.

42. Patlolla RR, Chougule M, Patel AR, Jackson T, Tata PN, Singh M. Formulation, characterization and pulmonary deposition of nebulized celecoxib encapsulated nanostructured lipid carriers. J Controlled Release 2010;144:233-41.

43. Trotta M, Debernardi F, Caputo 0. Preparation of solid lipid nanoparticles by a solvent emulsification-diffusion technique. Int J Pharm 2003;257:153-60.

44. Mojahedian MM, Daneshamouz S, Samani SM, Zargaran A. A novel method to produce solid lipid nanoparticles using $\mathrm{n}$ butanol as an additional co-surfactant according to the $\mathrm{o} / \mathrm{w}$ microemulsion quenching technique. Chem Phys Lipids 2013; 174:32-8

45. Serpe L, Laurora S, Pizzimenti S, Ugazio E, Ponti R, Canaparo R, et al. Cholesteryl butyrate solid lipid nanoparticles as a butyric acid pro-drug: effects on cell proliferation, cell-cycle distribution and c-myc expression in human leukemic cells. Anti-Cancer Drugs 2004;15:525-36.

46. Morel S, Terreno E, Ugazio E, Aime S, Gasco MR. NMR relaxometric investigations of solid lipid nanoparticles (SLN) containing gadolinium (III) complexes. Eur J Pharm Biopharm 1998;45:157-63.

47. Rcavalli RC, Marengo E, Rodriguez L, Gasco MR. Effect of some experimental factors on the production process of solid lipid nanoparticles. Eur J Pharm Biopharm 1996;42:110-5.

48. Sarangi MK, Padhi S. Solid lipid nanoparticles-a review. J Crit Rev 2016;3:5-12.

49. Shah KA, Date AA, Joshi MD, Patravale VB. Solid lipid nanoparticles (SLN) of tretinoin: potential in topical delivery. Int J Pharm 2007;345:163-71.

50. Subedi RK, Kang KW, Choi HK. Preparation and characterization of solid lipid nanoparticles loaded with doxorubicin. Eur J Pharm Sci 2009;37:508-13.

51. Muller RH. Solid lipid nanoparticles (SLN)-an alternative colloidal carrier system for controlled drug delivery. Eur J Biopharm 1995;41:62-9.

52. Liu J, Gong T, Wang C, Zhong Z, Zhang Z. Solid lipid nanoparticles loaded with insulin by sodium cholate- phosphatidylcholine-based mixed micelles: preparation and characterization. Int J Pharm 2007;340:153-62.

53. Hippalgaonkar K, Adelli GR, Hippalgaonkar K, Repka MA, Majumdar S. Indomethacin-loaded solid lipid nanoparticles for ocular delivery: development, characterization, and in vitro evaluation. J Ocul Pharmacol Ther 2013;29:216-28.

54. Ali H, Shirode AB, Sylvester PW, Nazzal S. Preparation, characterization, and anticancer effects of simvastatintocotrienol lipid nanoparticles. Int J Pharm 2010;389:223-31.

55. Anitha A, Sreeranganathan M, Chennazhi KP, Lakshmanan VK, Jayakumar R. In vitro combinatorial anticancer effects of 5fluorouracil and curcumin loaded N, O-carboxymethyl chitosan nanoparticles toward colon cancer and in vivo pharmacokinetic studies. Eur J Pharm Biopharm 2014;88:238-51.

56. Zhang J, Han J, Zhang X, Jiang J, Xu M, Zhang D, et al. Polymeric nanoparticles based on chitooligosaccharide as drug carriers for co-delivery of all-trans-retinoic acid and paclitaxel. Carbohydr Polym 2015;129:25-34.

57. Dilnawaz F, Sahoo SK. Enhanced accumulation of curcumin and temozolomide loaded magnetic nanoparticles executes profound cytotoxic effect in glioblastoma spheroid model. Eur J Pharm Biopharm 2013;85:452-62.

58. Baek JS, Cho CW. Controlled release and reversal of multidrug resistance by co-encapsulation of paclitaxel and verapamil in solid lipid nanoparticles. Int J Pharm 2015;478:617-24.

59. Zhu R, Wu X, Xiao Y, Gao B, Xie Q, Liu H, et al. Synergetic effect of SLN-curcumin and LDH-5-Fu on SMMC-7721 liver cancer cell line. Cancer Biother Radiopharm 2013;28:579-87.

60. Wong HL, Bendayan R, Rauth AM, Wu XY. Simultaneous delivery of doxorubicin and GG918 (Elacridar) by new polymer-lipid hybrid nanoparticles (PLN) for enhanced treatment of multidrug-resistant breast cancer. J Controlled Release 2006;116:275-84.

61. Thakkar A, Chenreddy S, Wang J, Prabhu S. Ferulic acid combined with aspirin demonstrates chemopreventive potential towards pancreatic cancer when delivered using chitosan-coated solid-lipid nanoparticles. Cell Biosci 2015;5:46.

62. Sutaria D, Grandhi BK, Thakkar A, Wang J, Prabhu S. Chemoprevention of pancreatic cancer using solid-lipid nanoparticulate delivery of a novel aspirin, curcumin and sulforaphane drug combination regimen. Int $\mathrm{J}$ Oncol 2012;41:2260-8

63. Buyukkoroglu G, Șenel B, Bașaran E, Yenilmez E, Yazan Y. Preparation and in vitro evaluation of vaginal formulations including siRNA and paclitaxel-loaded SLNs for cervical cancer. Eur J Pharm Bipharm 2016;109:174-83.

64. Li S, Wang L, Li N, Liu Y, Su H. Combination lung cancer chemotherapy: Design of a pH-sensitive transferrin-PEG-Hzlipid conjugate for the co-delivery of docetaxel and baicalin. Biomed Pharmacother 2017;95:548-55.

65. Oliveira MS, Aryasomayajula B, Pattni B, Mussi SV, Ferreira LA, Torchilin VP. Solid lipid nanoparticles co-loaded with doxorubicin and $\alpha$-tocopherol succinate are effective against drug-resistant cancer cells in monolayer and 3-D spheroid cancer cell models. Int J Pharm 2016;512:292-300.

66. Buyukkoroglu G, Şenel B, Gezgin S, Dinh T. The simultaneous delivery of paclitaxel and Herceptin using solid lipid nanoparticles: in vitro evaluation. J Drug Delivery Sci Tech 2016;35:98-105.

67. Liu B, Han L, Liu J, Han S, Chen Z, Jiang L. Co-delivery of paclitaxel and TOS-cisplatin via TAT-targeted solid lipid nanoparticles with synergistic antitumor activity against cervical cancer. Int J Nanomed 2017; 12:955-68.

68. Thakkar A, Chenreddy S, Wang J, Prabhu S. Evaluation of ibuprofen loaded solid lipid nanoparticles and its combination regimens for pancreatic cancer chemoprevention. Int J Oncol 2015;46:1827-34.

69. Wang Y, Zhang H, Hao J, Li B, Li M, Xiuwen W. Lung cancer combination therapy: co-delivery of paclitaxel and doxorubicin by nanostructured lipid carriers for synergistic effect. Drug Delivery 2016;23:1398-403. 